\title{
KORELASI METODE DISKUSI DENGAN HASIL BELAJAR SISWA PADA PEMBELAJARAN BAHASA INDONESIA KELAS VIII MTS TAKWA GUMAWANG
}

\author{
Sari Purnama Putri Wir'atmaja ${ }^{1^{\star}}$, Sugiarti $^{2 \star}$, Hastuti Retno Kuspiyah ${ }^{3 \star}$ \\ Program Studi Pendidikan Bahasa dan Sastra Indonesia \\ STKIP Nurul Huda OKU Timur \\ giarti@stkipnurulhuda.ac.id \\ retno@stkipnurulhuda.ac.id
}

\begin{abstract}
Abstrak
Rumusan masalah dalam penelitian ini adalah apakah terdapat hubungan antara metode diskusi terhadap hasil belajar siswa dalam pembelajaran bahasa Indonesia kelas VIII MTs Takwa Gumawang?. Penelitian ini bertujuan untuk mengetahui seberapa tingkat hubungan hasil belajar siswa yang diajarkan dengan metode diskusi pada pembelajaran bahasa Indonesia. Metode yang digunakan dalam penelitian ini yaitu deskriptif dengan pendekatan korelasional. Populasi dalam penelitian ini yaitu kelas VIII MTs Takwa Gumawang yang berjumlah 47 responden. Sampel diambil dengan menggunakan simple random sampling, yaitu pengambilan sampel secara acak, dan kelas yang terpilih yaitu kelas VIII 2 berjumlah 23 responden. Pengumpulan data dalam penelitian ini menggunakan angket dan dokumentasi berupa nilai rapot (semester gazal). Peneliti membahas ada tidaknya hubungan antara metode diskusi terhadap hasil belajar siswa, yang dihipotesiskan dalam hipotesisi alternatif (Ha), hipotesis diterima jika terdapat hubungan yang signifikan antara metode diskusi terhadap hasil belajar siswa. Hasil perhitungan variabel metode diskusi, diketahui nilai minimum sebesar 70 dan maximum sebesar 95. Hasil perhitungan dari nilai belajar siswa, diketahui nilai minimum sebesar 84 dan maximum 87 . Selanjutnya dari hasil analisis korelasi dikatakan variabel mempunyai hubungan apabila nilai signifikasi lebih kecil dari 0,05. Diketahui nilai signifikan metode diskusi terhadap hasil belajar yaitu 0,01, dimana 0,01 > 0,05. Peneliti menyimpulkan bahwa terdapat pengaruh antara metode diskusi terhadap hasil belajar siswa.
\end{abstract}

Kata Kunci: Diskusi, Hasil Belajar

\section{PENDAHULUAN}

Menurut Baharuddin (2009:11), belajar pada intinya adalah proses memperoleh berbagai pengetahuan (kognitif), keterampilan (psikomotorik), dan sikap (afektif). Proses belajar ini dapat terjadi disekolah maupun diluar sekolah. Sebagai salah satu lembaga yang menyelenggarakan pendidikan formal, sekolah mempunyai peranan penting dalam pendewasaan peserta didik menjadi masyarakat yang berguna. Untuk tujuan tersebut sekolah menyelenggarakan kegiatan belajar mengajar dan kurikulum sebagai wadah dan bahan mentahnya.

Pada proses belajar mengajar, guru memegang peranan yang sangat penting, tetapi tidak bisa dipisahkan peranan siswa dalam pencapain tujuan pendidikan, khususnya dalam hal penerimaan materi pelajaran. Agar pembelajaran lebih efektif guru dituntut untuk menguasai management kelas atau sering juga disebut pengelolaan kelas. Di dalam kelas guru tidak hanya bertugas menyampaikan materi saja, tetapi juga harus mampu mewujudkan suasana belajar yang menyenangkan. Guru yang berada pada baris depan dalam membentuk pribadi siswa. Guru juga yang menentukan berhasil atau tidaknya dari hasil belajar.

Keberhasilan proses belajar mengajar merupakan hal utama yang didambakan dalam melaksanakan pendidikan disekolah. Hasil belajar merupakan hasil dari suatu interaksi tindak belajar dan tindak mengajar (Mudjiono, 2013:3). Hasil belajar adalah tujuan pendidikan dalam proses pembelajaran sehingga dapat mengetahui dan memahami pengetahuan yang diterimanya selama proses pembelajaran.

Keberhasilan peserta didik untuk memperoleh pendidikan tidak mudah, terdapat beberapa 
faktor. Keberhasilan peserta didik tidak hanya ditentukan oleh faktor pengajaran dalam kelas saja, tetapi tidak terlepas dari faktor peserta didik itu sendiri, misalnya aktifitas belajar, minat dalam belajar, kemampuan, memotivasi belajar. Jika dilihat dari sudut pandang siswa, untuk mencapai hasil belajar yang baik tentu tidak terlepas dari faktor-faktor yang mempengaruhi proses belajar, baik dari dalam maupun dari luar diri siswa itu sendiri. Faktor yang berasal dari dalam antara lain adalah kecerdasan, bakat, minat belajar serta kemampuan dan cara berfikir siswa yang berbeda-beda. Sedangkan untuk faktor dari luar antara lain yaitu, lingkungan keluarga, lingkungan sekolah, dan lingkungan masyarakat.

Keaktifan siswa dalam belajar merupakan persoalan penting dan mendasar yang harus dipahami, didasari dan dikembangkan oleh setiap guru dalam keberhasilan proses pembelajaran. Ketika siswa belajar dengan aktif, berarti siswa yang mendominasi aktivitas pembelajarannya. Dengan belajar aktif ini, siswa diajak untuk turut serta dalam semua proses pembelajaran yang tidak hanya secara fisik tetapi juga melibatkan mental, selain itu belajar aktif juga menuntut adanya interaksi antara guru dengan siswa, siswa dengan siswa, maupun siswa dengan sumber atau media belajar. Dalam proses belajar mengajar keberhasilan ditentukan oleh tercapinya tujuan pembelajaran, hal tersebut harus didukung oleh pemilihan metode yang sesuai serta alat penilain yang dapat mengukur keberhasilan dari proses belajar mengajar.

Metode adalah segala upaya untuk mengimplementasikan rencana yang sudah disusun dalam kegiatan nyata agar tujuan pembelajaran yang diinginkan dapat tercapai secara optimal (Jufri, 2013:5). Dalam proses belajar mengajar terdapat banyak metode yang digunakan oleh seorang guru dalam menyampaikan materi pelajaran. Dalam penelitian ini penulis memilih metode diskusi dalam melaksanakan proses pembelajaran. Metode diskusi merupakan interaksi antara siswa dengan siswa, siswa dengan guru untuk menganalisis, memecahkan masalah, menggali, memperdebatkan topik atau permasalahan tertentu (Aqib, 2014:107).

Menurut Gulo (dikutip Mujin, 2013:57), metode diskusi merupakan metode pembelajaran yang tepat untuk meningkatkan kualitas interaksi antara peserta didik. Tujuannya ialah untuk memperoleh pengertian bersama yang lebih jelas dan lebih teliti tentang sesuatu, disamping untuk mempersiapkan dan menyelesaikan keputusan bersama. Metode diskusi dalam pembelajaran merupakan alternatif yang sangat baik bagi guru untuk digunakan dalam proses penyampain informsi atau pelajaran, karena metode diskusi merupakan sarana untuk saling bertukar pikiran secara lisan. Dengan menggunakan metode ini diharapkan siswa lebih aktif dalam kegiatan belajar mengajar. Sebagai dampak dari kektifan itu tentunya menjadi tujuan dari proses belajar yaitu hasil belajar yang sangat baik dapat mencapai secara optimal.

Mengajar menggunakan metode diskusi, menambah erat antara siswa dan guru, siswa dengan siswa sehingga proses belajar mengajar dapat tercipta dengan baik. Menurut Wakhinuddin (20), metode diskusi adalah metode yang menerapkan kebebasan bagi siswa untuk bercerita, sehingga dua siswa atau lebih membahas suatu topik permasalahan secara informal yang bertujuan untuk membagi pengalaman, mengemukakan pendapat, mendiskusikan berbagai alternatif, dan melakukan apa yang sudah direncanakan sehingga terjadi interaksi antara individu yang ada di dalam kelompok atau interaksi antar kelompok yang berguna untuk pemecahan masalah dan merencanakan sesuatu yang efektif.

\section{METODE PENELITIAN}

Metode penelitian suatu cara yang digunakan dalam penelitian. Jenis penelitian yang digunakan adalah kuantitatif. Metode penelitian yang digunakan yaitu deskriptif dengan pendekatan korelasional. Metode ini mempunyai tujuan untuk mendeskripsikan hasil penelitian (objek). Menurut Sugiyono (2012:29) deskriptif adalah metode yang berfungsi untuk mendeskripsikan atau memberi gambaran terhadap objek yang diteliti melalui data atau sampel yang telah terkumpul sebagaimana adanya, tanpa melakukan analisis dan membuat kesimpulan yang berlaku umum. Sedangkan, pendekatan korelasional adalah penelitian yang dilakukan untuk mengetahui hubungan antar variabel (Arikunto, $2014:$ 313).

\section{HASIL DAN PEMBAHASAN}

Berdasarkan data yang diperoleh, maka dapat disajikan pengelolahan data yang berupa analisis data. Berikut hasil penelitian ini:

Sari Purnama P., Sugiarti, dan Hastuti Retno K. 


\section{Analisis Statistik Deskriptif}

Statistik deskriptif digunakan untuk memberikan gambaran tentang data yang diteliti. Analisis statistik deskriptif dalam penelitian ini dihitung dengan menggunakan program SPSS versi 16.0 dengan bantuan komputer. Deskriptif data digunakan untuk memperoleh gambaran tentang masingmasing variabel, maka digunakan analisis statistik deskriptif. Deskriptif data tersebut meliputi tabel frekuensi, histogram, mean, median, modus, dan standar deviasi. Berikut analisis statistik deskriptif masing-masing variabel:

\section{a. Penggunaan Angket Metode Diskusi}

Mengetahui hubungan metode diskusi, peneliti mengumpulkan data dengan menggunakan angket yang terdiri dari 20 pertanyaan dan memiliki 2 alternatif jawaban, yaitu "Ya" dan "Tidak". Nilai angket dapat dilihat pada tabel dibawah ini :

Tabel 1

Statistik Deskriptif

Descriptive Statistics

\begin{tabular}{|l|c|c|c|c|c|c|c|c|c|c|c|c|}
\hline & $\mathbf{N}$ & Range & Min & Max & Sum & Mean & \multicolumn{2}{c|}{$\begin{array}{c}\text { Std. } \\
\text { Deviation }\end{array}$} & Variance & \multicolumn{2}{|c|}{ Skewness } & \multicolumn{2}{c|}{ Kurtosis } \\
\hline & $\begin{array}{c}\text { Statis } \\
\text { tic }\end{array}$ & $\begin{array}{c}\text { Statist } \\
\text { ic }\end{array}$ & $\begin{array}{c}\text { Stati } \\
\text { stic }\end{array}$ & $\begin{array}{c}\text { Statis } \\
\text { tic }\end{array}$ & $\begin{array}{c}\text { Statis } \\
\text { tic }\end{array}$ & $\begin{array}{c}\text { Statis } \\
\text { tic }\end{array}$ & Statistic & Statistic & Statistic & $\begin{array}{c}\text { Std. } \\
\text { Error }\end{array}$ & $\begin{array}{c}\text { Statis } \\
\text { tic }\end{array}$ & $\begin{array}{c}\text { Std. } \\
\text { Error }\end{array}$ \\
\hline $\begin{array}{l}\text { Metode } \\
\text { Diskusi }\end{array}$ & 23 & 25 & 70 & 95 & 1865 & 81.09 & 9.765 & 95.356 & .067 & .481 & -1.665 & .935 \\
\hline $\begin{array}{l}\text { Valid N } \\
\text { (listwise) }\end{array}$ & 23 & & & & & & & & & & & \\
\hline
\end{tabular}

Hasil data yang diperoleh dari statistik deskriptif diatas yaitu hasil penilaian dengan jumlah data 23 responden. Diperoleh nilai minimum 70 dan maksimum 95 dengan jumlah keseluruhan 1865 . Nilai rata-rata sebesar 81,09 , standar deviasi 9,765 , skwenes sebesar 0,67 , dan kuortis sebesar 1,665 .

\section{b. Statistik Deskriptif Hasil Belajar Siswa}

Hasil belajar siswa diperoleh dari nilai akhir semester (nilai rapot). Nilai tersebut hasil belajar siswa selama satu semester berdasarkan silabus bahasa Indonesia kelas VIII MTs Takwa Gumawang. Berikut hasil penelitian yang diperoleh dari data hasil belajar siswa berupa nilai rapot.

Tabel 2

Descriptive Statistics

Statistik Deskriptif Hasil Belajar Siswa

\begin{tabular}{|c|c|c|c|c|c|c|c|c|c|c|c|c|}
\hline & \multirow{2}{*}{$\frac{\mathbf{N}}{\underset{\text { Statis }}{\text { tic }}}$} & \multirow{2}{*}{ 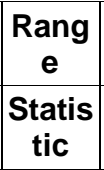 } & \multirow{2}{*}{\begin{tabular}{|c} 
Min \\
$\begin{array}{c}\text { Statis } \\
\text { tic }\end{array}$
\end{tabular}} & \multirow{2}{*}{$\begin{array}{c}\text { Max } \\
\text { Statis } \\
\text { tic }\end{array}$} & \multirow{2}{*}{$\begin{array}{c}\text { Sum } \\
\begin{array}{c}\text { Statis } \\
\text { tic }\end{array}\end{array}$} & \multirow{2}{*}{\begin{tabular}{|c|} 
Mean \\
$\begin{array}{c}\text { Statis } \\
\text { tic }\end{array}$ \\
\end{tabular}} & \multirow{2}{*}{$\begin{array}{c}\begin{array}{c}\text { Std. } \\
\text { Deviation }\end{array} \\
\text { Statistic }\end{array}$} & \multirow{2}{*}{\begin{tabular}{|c|}
$\begin{array}{c}\text { Varia } \\
\text { nce }\end{array}$ \\
$\begin{array}{c}\text { Statis } \\
\text { tic }\end{array}$ \\
\end{tabular}} & \multicolumn{2}{|c|}{ Skewness } & \multicolumn{2}{|c|}{ Kurtosis } \\
\hline & & & & & & & & & $\begin{array}{c}\text { Statis } \\
\text { tic }\end{array}$ & $\begin{array}{l}\text { Std. } \\
\text { Error }\end{array}$ & $\begin{array}{c}\text { Statis } \\
\text { tic }\end{array}$ & \begin{tabular}{|l|} 
Std. \\
Error
\end{tabular} \\
\hline $\begin{array}{l}\text { Hasil } \\
\text { Belajar } \\
\text { Siswa }\end{array}$ & 23 & 3 & 84 & 87 & 1970 & 85.65 & .775 & .601 & .081 & .481 & -.292 & .935 \\
\hline \begin{tabular}{|l} 
Valid N \\
(listwise)
\end{tabular} & 23 & & & & & & & & & & & \\
\hline
\end{tabular}

Berdasarkan hasil data yang diperoleh dari statistik deskriptif diatas, nilai minimum sebesar 84 dan nilai maximum 87 dengan jumlah nilai 1970. Nilai rata-rata yang diperoleh 85,65, standar deviasi 0,775 . Hasil skweness 0,081 dan kurtosis $-0,292$. Dilihat dari hasil statistik deskriptif, hasil belajar siswa dapat di golongkan dalam kriteria penilaian. Kriteria penilaian dalam penelitian ini dapat dilihat pada tabel dibawah ini: 
Tabel 3

Kriteria Penilaian Hasil Belajar Siswa

\begin{tabular}{|c|c|c|c|c|}
\hline No & Nilai & Kriteria & \multicolumn{2}{|c|}{ Nilai } \\
\cline { 3 - 5 } & & & F & $\%$ \\
\hline 1. & $81-100$ & Sangat Baik & 23 & 100 \\
\hline 2. & $61-80$ & Baik & 0 & 0 \\
\hline 3. & $41-60$ & Cukup & 0 & 0 \\
\hline 4. & $21-40$ & Jelek & 0 & 0 \\
\hline 5. & $1-20$ & Sangat Jelek & 0 & 0 \\
\hline \multicolumn{2}{|c|}{ Total } & 23 & 100 \\
\hline
\end{tabular}

Dari hasil kriteria penilaian hasil belajar siswa dalam pembelajaran Bahasa Indonesia dapat dilihat bahwa diperoleh 23 siswa dalam kriteria sangat baik, yaitu dengan nilai 81 - 100 dengan presentasi $100 \%$. Terlihat dari hasil belajar yang diambil dari nilai rapot menunjukan hasil yang memuaskan.

\section{Analisis Data}

\section{a. Uji Normalitas}

Uji normalitas dalam penelitian ini menggunakan teknik kolmogrov-smirno. Uji normalitas ini untuk mengetahui normal atau tidaknya data yang menjadi penelitian. Suatu data dapat dikatakan berdistribusi normal apabila nilai signifikasi lebih besar dari 0,05. Data tidak dikatakan berdistribusi normal apabila nilai signifikasi kurang dari 0,05 . Berikut hasil uji normalitas menggunakan program SPSS versi 16:

Tabel 4

Uji Normalitas

Tests of Normality

\begin{tabular}{|l|c|c|c|c|c|c|}
\hline & \multicolumn{3}{|c|}{ Kolmogorov-Smirnov $^{\mathbf{a}}$} & \multicolumn{3}{c|}{ Shapiro-Wilk } \\
\hline & Statistic & Df & Sig. & Statistic & Df & Sig. \\
\hline $\begin{array}{l}\text { Pengaruh Metode } \\
\text { Diskusi }\end{array}$ & .218 & 23 & .006 & .836 & 23 & .002 \\
\hline $\begin{array}{l}\text { Hasil Belajar } \\
\text { Siswa }\end{array}$ & .238 & 23 & .002 & .859 & 23 & .004 \\
\hline
\end{tabular}

a. Lilliefors Significance Correction

Berdasarkan hasil perhitungan diatas, diketahui bahwa nilai signifikasi 0,06 . Data yang diperoleh dari pengaruh metode diskusi berdistribusi normal karena $0,06>0,05$. Sedangkan nilai signifikasi hasil belajar siswa 0,02.

\section{b. Uji Linearitas}

Uji linearitas digunakan untuk mengetahui ada tidaknya hubungan yang linear pada variabel $X$ dan variabel $Y$. Hubungan linear variabel $X$ dan variabel $Y$ di uji dengan taraf signifikan. Dikatakan linear jika taraf signifikan lebih besar dari 0,05 . Selain itu juga dapat dilihat dari kriteria penguji linearitas jika $\mathrm{F}$ hitung lebih kecil dari $\mathrm{F}$ tabel. $\mathrm{F}$ tabel dapat dilihat dari tabel distribusi $\mathrm{F}$ dengan taraf signifikan $5 \%$. Berikut hasil uji linearitas menggunakan program spss versi 16 :

Tabel 5

Uji Linearitas

ANOVA Table

\begin{tabular}{|c|c|c|c|c|c|c|c|}
\hline & & & $\begin{array}{l}\text { Sum of } \\
\text { Squares }\end{array}$ & df & $\begin{array}{c}\text { Mean } \\
\text { Square }\end{array}$ & $\mathbf{F}$ & Sig. \\
\hline \multirow{5}{*}{$\begin{array}{l}\text { Hasil Belajar } \\
\text { Siswa } \\
\text { Pengaruh } \\
\text { Metode } \\
\text { Diskusi }\end{array}$} & \multirow{3}{*}{$\begin{array}{l}\text { Beteen } \\
\text { Groups }\end{array}$} & (Combined) & 6.392 & 5 & 1.278 & 3.184 & .033 \\
\hline & & Linearity & 5.430 & 1 & 5.430 & $\begin{array}{l}13.52 \\
5\end{array}$ & .002 \\
\hline & & $\begin{array}{l}\text { Deviation from } \\
\text { Linearity }\end{array}$ & .963 & 4 & .241 & .599 & .668 \\
\hline & \multicolumn{2}{|c|}{ Within Groups } & 6.825 & 17 & .401 & & \\
\hline & \multicolumn{2}{|l|}{ Total } & 13.217 & 22 & & & \\
\hline
\end{tabular}

Sari Purnama P., Sugiarti, dan Hastuti Retno K. 
Hasil perhitungan uji linearitas dalam penelitian ini signifikan yaitu 0,668. Dapat disimpulkan bahwa kedua variabel bersifat linear karena nilai signifikan 0,668 $>0,05$. Sedangkan nilai t 0,599 dan $F_{\text {tabel }}$ sebesar 1,27.

\section{c. Analisis Korelasi}

Analisis korelasi bertujuan untuk mengetahui ada tidaknya hubungan antara variabel bebas dan variabel terikat. Ketentuan nilai signifikan analisis korelasi adalah jika nilai signifikan $<0,05$, maka terdapat korelasi (hubungan), dan jika nilai signifikasi $>0,05$ tidak terdapat korelasi (hubungan) antara variabel $\mathrm{X}$ dan variabel $\mathrm{Y}$.

\begin{tabular}{|c|c|c|c|}
\hline \multicolumn{4}{|c|}{ Correlations } \\
\hline & & $\begin{array}{c}\text { Pengaruh } \\
\text { Metode Diskusi }\end{array}$ & $\begin{array}{l}\text { Hasil Belajar } \\
\text { Siswa }\end{array}$ \\
\hline \multirow{3}{*}{$\begin{array}{l}\text { Pengaruh } \\
\text { Metode } \\
\text { Diskusi }\end{array}$} & Pearson Correlation & 1 & $-.638^{* x}$ \\
\hline & Sig. (2-tailed) & & . 001 \\
\hline & $\mathbf{N}$ & 23 & 23 \\
\hline \multirow{3}{*}{$\begin{array}{l}\text { Hasil } \\
\text { Belajar } \\
\text { Siswa }\end{array}$} & Pearson Correlation & $-.638^{\prime \prime}$ & 1 \\
\hline & Sig. (2-tailed) & .001 & \\
\hline & $\mathbf{N}$ & 23 & 23 \\
\hline
\end{tabular}

${ }^{* *}$. Correlation is significant at the 0.01 level (2-tailed).

Hasil perhitungan analisis korelasi diatas dapat disimpulkan bahwa nilai signifikasi $0,01<$ 0,05. Maka dapat dikatakan terdapat korelasi antara metode diskusi dan hasil belajar siswa dalam pembelajaran bahasa Indonesia.

\section{Pembahasan}

Keberhasilan proses belajar mengajar merupakan hal utama yang ingin dicapai dalam melaksanakan pendidikan disekolah. Hasil belajar merupakan hasil dari suatu interaksi tindak belajar dan tindak mengajar. Dalam proses belajar mengajar keberhasilan ditentukan oleh tercapainya tujuan pembelajaran, hal tersebut harus didukung dengan pemilihan metode pembelajaran. Metode adalah segala upaya untuk mengimplementasikan rencana yang sudah disusun dalam kegiatan nyata agar tujuan pembelajaran yang diingikan dapat tercapai secara optimal.

Penelitian ini membahas salah satu metode, yaitu metode diskusi. Metode diskusi dalam pembelajaran adalah cara penyampaian bahan pelajaran dimana guru memberikan kesempatan kepada siswa untuk mengumpulkan pendapat, membuat kesimpulan atau menyusun berbagai alternatif pemecahan masalah. Pengumpulan data dalam penelitian ini berupa angket metode diskusi dan dokumentasi berupa nilai rapot semester genap kelas VIII MTs Takwa Gumawang.

Peneliti membahas ada tidaknya hubungan antara metode diskusi terhadap hasil belajar siswa, yang dihipotesiskan dalam Hipotesis Alternatif $(\mathrm{Ha})$ diterima jika ada hubungan yang signifikan antara metode diskusi terhadap hasil belajar siswa. Penelitian dilakukan di MTs Takwa Gumawang. Teknik pemilihan sampel kelas yaitu menggunakan simple random sampling, yang mana kelas dipilih secara acak. Cara yang digunakan untuk memilih kelas yaitu dengan cara mengundi 2 kelas yaitu VIII 1 Al Jabar dan VIII 2 Al Mujib. Kelas yang terpilih dari hasil undian yaitu kelas VIII 2 Al Mujib dengan jumlah 23 responden. Penelitian ini terdapat dua variabel yaitu variabel bebas (pengaruh metode diskusi) dan variabel terikat (hasil belajar siswa).

Setelah dilakukan perhitungan menggunakan program spss versi 16 , ditemukan hubungan antara kedua variabel. Hasil perhitungan variabel pengaruh metode diskusi nilai minimum sebesar 70 dan maximum sebesar 95. Nilai rata-rata diperoleh sebesar 81,09 dengan standar deviasi sebesar 9,765 . Hasil perhitungan variabel hasil belajar siswa yang dilihat dari nilai rapot ditemukan nilai minimum 84 dan maximum 87. Nilai rata-rata diperoleh sebesar 85,65 dengan standar deviasi 775 .

Selanjutnya dari perhitungan analisis korelasi variabel metode diskusi dan hasil belajar siswa dapat disimpulkan berkorelasi atau memiliki hubungan. Hal ini dapat dibuktikan dari hasil korelasi bahwa nilai signifikasi $0,01<0,05$, yang mana nilai signifikasi lebih kecil dari $r$ tabel. Perhitungan 
tersebut berarti hipotesisi diterima dan terdapat hubungan antara metode diskusi terhadap hasil belajar siswa dalam pembelajaran bahasa Indonesia.

\section{PENUTUP}

Berdasarkan hasil penelitian dan pembahasan dapat disimpulkan bahwa metode diskusi terhadap hasil belajar siswa dalam pembelajaran bahasa indonesia kelas VIII di MTs Takwa Gumawang yaitu terdapat hubungan antara variabel $X$ dan variabel $Y$. Hasil perhitungan variabel metode diskusi nilai minimum sebesar 70 dan maximum sebesar 95 .

Hasil perhitungan variabel hasil belajar siswa yang dilihat dari nilai rapot ditemukan nilai minimum 84 dan maximum 87 . Nilai rata-rata diperoleh sebesar 85,65 dengan standar deviasi 0,775. Nilai hasil belajar siswa kelas VIII MTs Takwa Gumawang dapat dikategorikan sangat baik. Dengan hasil belajar yang dilihat dari nilai rapot semester genap.

Selanjutnya dari analisis korelasi variabel metode diskusi dan hasil belajar siswa berkorelasi atau berhubungan. Hal ini dapat dibuktikan dengan hasil analisis korelasi $0,01<0,05$. Peneliti menyimpulkan bahwa terdapat pengaruh antara metode diskusi terhadap hasil belajar dalam pembelajaran bahasa Indonesia.

\section{UCAPAN TERIMAKASIH}

Ucapan terimakasih ditujukan kepada ketua STKIP Nurul Huda dan TIM peneliti.

\section{DAFTAR PUSTAKA}

Aqib, Zainal. 2014. Model-Model, Media dan Strategi Pembelajaran Kontestual (Inovatif). Bandung: Yrama Widya.

Arikunto, Suharsimi. 2014. Prosedur Penelitian, Suatu Pendekatan Praktik. Jakarta: Rineka Cipta.

Badariah, Normin. 2013. Pengaruh Metode Diskusi terhadap Hasil Belajar Bahasa Indonesia Siswa Kelas XI Sekolah Menengah Atas Negeri Bintan Tahun Pelajaran 2012-2013.E-Jurnal.

Chandra, Reo. 2013. Pengaruh Metode Diskusi terhadap Hasil Belajar Siswa pada Pembelajaran Ekonomi Kelas X Sekolah Menengah Atas Negeri 3 Bangku Pusoko Kabupaten Rokan Hilir.

Kemendikbud. 2014. Buku Guru Bahasa Indonesia. Jakarta: Kementerian Pendidikan dan Kebudayaan.

Prihatin, Effiyati. 2017. Pengaruh Metode Pembelajaran dan Minat Belajar terhadap Hasil Belajar.107.https://ejoural.undiksha.ac.id.

Purwanto. 2010. Evaluasi Hasil Belajar.Yogyakarta: Pustaka Pelajar

Setyorini D. 2012. Jurnal Pendidikan Akutansi Indonesia. journal.ac.id

Sugiyono. 2012. Metode Penelitian Kuantitatif, Kualitatif, dan R\&D. Bandung: Alfabeta.

Sugiyono. 2016. Metode Penelitian Kuantitatif, Kualitatif, dan R\&D. Bandung: Alfabeta.

Suryaman, Maman. 2012. Pengaruh Metode Diskusi terhadap Kemampuan Mengidentifikasi Jenis Karangan Siswa Kelas XI SMK Al Kausar Jakarta Tahun Ajaran 2011/2012.UIN Syarif Hidayatullah.

STKIP Nurul Huda Sukaraja. 2018. Pedoman Penulisan Skripsi. Program Studi Pendidikan Bahasa dan Sastra Indonesia.

Suryaman, Maman. 2012. Pengaruh Metode Diskusi terhadap Kemampuan Mengidentifikasi Jenis Karangan Siswa Kelas XI SMK Al Kausar Jakarta Tahun Ajaran 2011/2012. UIN Syarif Hidayatullah.

Suryanto dan Siswanto. 2018. Metode Kuantitatif Korelasional. Klaten: Bosscript. 
KORELASI METODE DISKUSI DENGAN HASIL BELAJAR.... $\mid 7$ Wakhinudin. Metode Diskusi. 2010. ejournal.unp.ac.id.16 Juni 2020.

Zalmita, Novia. 2014. Pengaruh Penggunaan Metode Diskusi Terhadap Kemampuan Berpikir Rasional Siswa dalam Pembelajaran IPS di SMP Negeri 1 Cipeucang Kabupaten Pandeglang. Universitas Pendidikan Indonesia. 